ISSN: 2614-1280, http://www.jurnal.stie-aas/ijebar

\title{
Innovation Orientation and Excellence Compete As Performance Determinant Components: Antecedents Orientation Variable of Entrepreneurship and Learning
}

\author{
Darmanto \\ darmanto.pignateli@gmail.com \\ STIE St. Pignatelli Surakarta
}

\begin{abstract}
: This study aims to provide information about the conceptual controversy regarding Orientation of Innovation and Competitive Advantage as Performance Determinant Components: Entrepreneurial and Entrepreneurial Antecedents Variables. The population of this research is the owner, manager and / or batik business employees in Batik Kauman village, Laweyan. The purpose sampling method was used and determined 100 samples. Motivation analysis used is Structural Equation Modeling (SEM) analysis with Lisrel software.The results of this study states that the orientation of innovation and competitive advantage had a positive and significant effect on performance. Entrepreneurship and Learning positively and significantly influence on innovation orientation and competitive advantage.

Keywords

\section{: Innovation Orientation, Competitive Advantage, Entrepreneurship, Learning, Performance}

\section{Introduction}

The development of Micro, Small and Medium Enterprises which are often termed as MSMEs in terms of quantity has increased, but it has not been matched by quality improvements, including here is Batik SMEs. Improving the quality of MSMEs can be done by implementing a strategy orientation mix (Altindag, Zehir \& Acar (2011). Batik is not just clothes for Indonesian people but also the identity of Indonesian people especially Solo. Solo Batik entrepreneurs more than $80 \%$ are businesses that have been done by their parents. Batik entrepreneurs are hereditary efforts. The development of batik both in quantity and quality is still very necessary to be improved (Purnomo, 2017).

Entrepreneurship to establish Micro, Small and Medium Enterprises which is often called SMEs, especially the business of batik cloth and batik clothes is an alternative choice of some scholars to live more prosperous, independent and help many people overcome unemployment. SMEs in Solo batik Solo is a mainstay of the economy, especially when the 1998 crisis, although managed simply, at that time they have taken a big role. MSMEs have positive and negative characteristics. The positive characteristics of MSMEs are resilience, flexibility, independence, efficiency, self-financing while the negative characteristics are informal, low economies of scale, no standards and SOPs, have not applied management principles, are not prepared to be big or grow, limited development (, 2009).

The research on the effect of innovation and performance orientation also yields different findings. Mavondo, Felix, Chimhanzi, Jacqueline, Stewart and Jillian (2005) produce findings that innovation orientation does not have a significant influence on organizational effectiveness. 


\section{Vol-2, Issue-2, 2018 (IJEBAR)}

ISSN: 2614-1280, http://www.jurnal.stie-aas/ijebar
Darmanto (2014) stated that negative technical innovation orientation is not significant on performance. Jhonson, Dibrell and Eric (2009), the results of his research stated that the orientation of integrated innovation has a positive effect on the performance of manufacturing industry companies. Companies are more successful if more focused on innovation activities. Based on the description, it shows that there are differences in the results of research on the effect of innovation orientation on organizational performance. Competitive advantage competitiveness advantage) according to Michael E Porter (2008) is the ability of a company to achieve economic benefits over the profit that can be achieved by competitors in the market in the same industry. Companies that have a competitive advantage always have the ability to understand changes in market structure and are able to choose an effective marketing strategy.

The influence of competitive advantage on performance is still different, some say no effect but some say positive and significant influence even some say very influential. The low performance of marketing is determined by the weakness of competitive advantage (Li \& Zhou, 2010; Gurhan et al., 2011). Competitive advantages consist of excellence in products and market excellence. This competitive advantage affects performance. Competitive advantages in costs consist of cost in process and cost on the machine. Competitive advantages in processes and on machines affect performance (Ana et al., 2011; Francesco \& Mario, 2011).

The entrepreneurship orientation has a positive and significant influence on organizational commitment to learning, organizational commitment to learning positively and significantly related to the openmindedness and vision of the company. The entrepreneurial orientation and entrepreneurial behaviors enhance the competitor's orientation, market, and customer value in companies operating in a dynamic environment. Entrepreneurial orientation has a positive and significant influence on competitive advantage and competitor orientation (Foltean, 2007; Omar, Nwanko and Richards, 2008; Ma'atoofi \& Tajeddini, 2010; Andreas; Cristina, 2011; Basile, 2012). See this, in this study entrepreneurship orientation serve as an antecedent variable of competitive advantage variables and competitor orientation. Antecedent variables are variables that proceed. Before competitive advantage and competitor orientation affect organizational performance, this variable is affected first by entrepreneurial variables.

Learning orientation has a positive effect on the orientation of innovation. Learning orientation has positive and significant influence on innovation orientation and enhancing competitive advantage. On the other hand, entrepreneurship orientation has an effect on competitive advantage and innovation orientation. Learning orientation has a positive and significant influence on competitive advantage and innovation orientation (Gagne, 2009; Devlin et al., 2011; Hatice, 2012). Seeing this in this study learning orientation is treated as an antecedent variable of innovation orientation variables and competitive advantage. Innovation orientation variables and competitive advantage before influencing organizational performance are first influenced by learning orientation.

This study uses the antecedent variable, independent variable and dependent variable. Use these antecedent variables to find out the right way to optimize organizational performance. Company/MSMEs of Batik before increasing competitive advantage and competitor orientation must first improve the entrepreneurship orientation and learning orientation. Based on the business phenomenon, theories and research results that 


\section{Vol-2, Issue-2, 2018 (IJEBAR)}

ISSN: 2614-1280, http://www.jurnal.stie-aas/ijebar

have been described then the problem of this study as follows: 1 . Does the entrepreneurial orientation and learning orientation affect the innovation and competitive advantage? 2. Does the orientation of innovation and competitive advantage affect the performance?

This study aims to provide information on the influence of innovation orientation and competitive advantage on performance, entrepreneurial influence and learning orientation on competitive advantage and competitor orientation. The advantage of this study with the previous research is the use of two antecedent variables made of two independent variables.

\section{Research Method}

The flow of this research starts from describing the business phenomenon, literature review and then formulating the problem. The data collection, data analysis and interpretation of research analysis. Then, followed by compiled research report research. From this final report a national journal with ISBN is made, teaching materials used to improve learning in marketing courses and international journals.]

This research was conducted on entrepreneur and/or manager/or batik business employee located in batik Kauman village, Laweyan. This place is used as a research site because they have the same criteria and problems as businessmen and / or managers and / or employees of batik business in Central Java and National.

The research time used in this research is the time of cross section study because it is done nowadays, not directly related to past and future research. This study aims to determine the effect of antecedent variables on independent variables and the influence of independent variables on the dependent variable. This type of research is seen from its nature including causal research because it aims to examine the relationship between variable one with other variables (Sekaran, 2010). The relationship of variables tested in this research is the relationship of gender variables, age, education, experience, entrepreneurship, innovation, customer orientation, competitor, organizational performance.

Based on its use including basic research or pure research (research pure research) is research that aims to increase scientific knowledge or to find a new field of research means the usefulness of research results that are not immediately used but in the long term will be used. According to the field of research, this study includes the field of economics because this study examines the economic field of entrepreneurship, reward, competitor orientation, competitive advantage with organizational performance (Sekaran, 2010). The analysis unit of this study is batik seller as a person. The unit of analysis in the study is traders as individuals who will be asked for perceptions on the variables under study. So the unit of analysis of this study is individual.

The population of this research is the owner, manager and / or employee of the batik business in Kauman village, Laweyan. The samples in this study are 100 respondents. This number has met the usual statistics stipulation of 100 respondents. The sampling technique in this study uses convenience sampling which is a sampling technique with regard to certain conveniences. These ease for example: Easy looking for address, easy transportation, willing to be a respondent. It is using convenience sampling because there are batik traders who are not willing to be respondents. Variables in this study can be differentiated into independent variables, dependent and mediation. A variable can be positioned as an independent variable and can be positioned as a dependent variable or moderation variable. To facilitate the understanding of variables and types presented in 
ISSN: 2614-1280, http://www.jurnal.stie-aas/ijebar

Table 1.

\begin{tabular}{|c|l|l|}
\hline No & \multicolumn{1}{|c|}{ Variabe } & \multicolumn{1}{|c|}{ Jenis variable } \\
\hline 1 & Innovation Orientation & Independent \\
2 & Competitive advantage & Independent \\
3 & Performance & Dependent \\
4 & Entrepreunershi & Antesedent $\backslash$ \\
\hline
\end{tabular}

Source: developed for this study

The way how to measure and variable indicator are presented in Table 2.

\begin{tabular}{|c|c|c|}
\hline No & Variable & How to Measure \\
\hline 1 & $\begin{array}{l}\text { Innovation } \\
\text { Orientation }\end{array}$ & $\begin{array}{l}\text { Orientasi Inovasi merupakan inovasi yang dilakukan UMKM berkaitan } \\
\text { dengan produk baru, pelayanan baru, proses produksi baru, kualitas produk }\end{array}$ \\
\hline 2 & & $\begin{array}{l}\text { eunggulan kualitas produk yang dihasilkan, harga jual, biaya produksi, } \\
\text { emamnuan asset. kemamnuan skill dan kanasitas(Ana et al. 2011) }\end{array}$ \\
\hline 3 & $\begin{array}{l}\text { Entrepreunershi } \\
\text { p Orientation }\end{array}$ & $\begin{array}{l}\text { Orientasi Kewirausahaan diukur dengan lima item pertanyaan yang diadopsi } \\
\text { dari } \\
\text { kuesioner yang dikembangkan oleh Zhou et al., 2005. Setiap item }\end{array}$ \\
\hline 4 & $\begin{array}{l}\text { Learning } \\
\text { Orientation }\end{array}$ & $\begin{array}{l}\text { Pembelajaran merupakan proses UMKM yang menekankan pada penciptaan } \\
\text { pengetahuan baru, pengetahuan yang luas mengenai teknologi dan pasar dapat }\end{array}$ \\
\hline 5 & $\begin{array}{l}\text { Performance } \\
\text { organization }\end{array}$ & $\begin{array}{l}\text { Kinerja Pemasaran diukur dengan lima item pertanyaan yang diadopsi dari } \\
\text { kuesioner yang dikembangkan oleh (darmanto, 2014). }\end{array}$ \\
\hline
\end{tabular}

Source: Zhou et al., 2005, Mavondo et al., 2005, Kirca et al, 2005, Darmanto, (2014)

Definisi operasional

The operational definitions of the variables used in this study are as follows:

2.2 Innovation Orientation is an innovation that UMKM is doing related to new product, new service, new production process, product quality, better raw material (Jhonson et al., 2009).

2.3 Competitive advantage is the superiority of product quality, selling price, production cost, asset ability, skill and capacity (Ana et al., 2011)

2.4 The entrepreneurship orientation is the level of courage of SME leaders to be the first in product innovation, market, dare to take risks and take proactive action and independence in running the business (Zhou et al., 2005). While Nadrol et al. (010) defines the courage level of SME leaders to do Proactiveness, Innovation, Risk-taking, Autonomy and Competitive Aggressiveness. In this study using these two definitions because basically this definition is the same.

2.5 Learning Orientation Learning is a UMKM process that emphasizes the creation of new knowledge, a broad knowledge of technology and markets can 
be used as a basis for planning the operation of new technologies.

2.6 Organizational performance is defined as an effort to measure the performance of SMEs based on sales turnover, number of buyers, profits, and sales growth While Miler (2003) defines measures of SME performance based on sales (volume and value), sales to new customers, sales trends, market (volumes and values), market trends, Number of subscribers, Number of new customers, Number of new prospects. In this study using the definition of Voss and Voss, 2000 by adding indicators of profit growth. Because profit growth is crucial to success in the future.

Data collection techniques conducted in this study consist of questionnaire and literature review.

The data collecting method using questionnaire is done by sending the questions list to the respondents which consist of owner, entrepreneur, manager and the employee of Batik enterprise in Klewer market, Kampung Kauman and Kampung Laweyen. The literature reviews in this research namely the data from the previous research and the relevant theory with this research. This data is useful for writing background problems, developing hypotheses and analyzing data and discussion of the results of the analysis. Library study contributions in data analysis such as books (Ghozali, 2006) are used as a basis for determining the model to be fit or not.

The type of the data viewed from the source consists of primary data and secondary data. The primary data is data obtained directly from respondents through answers from questionnaires and observations. The primary data used in this research is data about the responses of respondents related to the variables studied are answers about the identity of respondents and answers of entrepreneurial variables, rewards, competitive advantage, competitor orientation and organizational performance. Secondary data is data obtained indirectly or through intermediaries. The secondary data used in this research is data about respondent's address obtained from trade department.

\section{Analysis Results}

\subsection{SEM Analysis Result}

The feasibility result of SEM analysis model is presented in Table 3.

Table 3 Goodness of Fit

\begin{tabular}{|l|l|c|l|}
\hline Goodness of Fit Indices & \multicolumn{1}{|c|}{ Cut off Value } & Result & \multicolumn{1}{c|}{ Description } \\
\hline Chi Square & Small & 212.733 & Good \\
\hline Probability & $\geq 0,05$ & 0.124 & Good \\
\hline RMSEA & $\leq 0,08$ & 0.28 & Good \\
\hline CMN/DF & $<2$ & 1.120 & Good \\
\hline NFI & $\geq 0,90$ & 0.918 & Good \\
\hline CFI & $\geq 0,95$ & 0.990 & Good
\end{tabular}

Based on Table 3 the feasibility test of the model can be expressed in this research model fit / decent / good. The most important feasibility test of this model is Chi square and probability. Chi square should be small, this small result is 229.6. Probability should be $\geq$ 0.05 , The result of this research is 0.250 . So the model in this research is Fit.

The results of this analysis is used to determine the effect of each variable that is 
International Journal of Economics, Business and Accounting Research (IJEBAR)

Peer Reviewed - International Journal

Vol-2, Issue-2, 2018 (IJEBAR)

ISSN: 2614-1280, http://www.jurnal.stie-aas/ijebar

CR value (Critical Ratio) is the amount of influence between the variables studied and $\mathrm{P}$ (Probability) is presented in Table 4 as follows:

Table 4 the result of SEM test

\begin{tabular}{|c|l|l|c|c|l|}
\hline No & \multicolumn{1}{|c|}{ Antesedent Variable } & \multicolumn{1}{|c|}{ Independent Variable } & CR & P & Description \\
\hline & Entrepreneurial & & & & Supported \\
1 & Orientation & Innovation Orientation & 2,358 & 0,019 & \\
\hline 2 & Learning Orientation & Innovation Orientation & 2.444 & 0,015 & Supported \\
\hline 3 & $\begin{array}{l}\text { Entrepreneurial } \\
\text { Orientation }\end{array}$ & Competitor Advantage & 2,390 & 0,020 & Supported \\
\hline 4 & Learning Orientation & Competitor Advantage & 2,500 & 0,018 & Supported \\
\hline &. Independent Vvariable & Dependent Variable & CR & P & \\
\hline 5 & Competitor Orientation & Performance & 3,182 & 0,008 & Supported \\
\hline 6 & Competitive Advantage & Performance & 2,558 & 0,013 & Supported \\
\hline
\end{tabular}

Source: 2018 processed data

\section{Discussion}

4.1 The Orientation of Entrepreneurship Influences The Innovation Orientation

The results of the analysis presented in table 4 shows that entrepreneurship has a significant positive effect on innovation orientation. The higher the level of entrepreneurship orientation, the higher the orientation level of innovation. These results are consistent with the results of the study from Omar et al., 2008; Andreas \& Marcus, 2010; Basile, 2012 which states that entrepreneurship orientation has a significant positive effect on innovation orientation. Besides that, Rock \& Agca, 2009 stated competitor orientation, proactive and risk influence on innovation orientation. Based on this description it can be said clearly that the entrepreneurial orientation has a significant positive effect on innovation orientation. This result is also very reasonable that people who have a high entrepreneurial spirit would like to innovate.

4.2 Learning Orientation Has Significant Positive Effect On Innovation Orientation

The results of the analysis presented in
Table 4 show that the orientation of learning has a significant positive effect on innovation orientation. These results are in line with Gajic \& Medved (2010) research, which states that learning outcomes and benefits enhance employee morale in innovating. Meanwhile Devlin et al. (2011) stated that the orientation of learning will increase the time savings. This means it is clear that learning orientation can improve the orientation of innovation. This result is a normative result that is a highly educated person likes melkukan innovative activity.

4.3 The Orientation Of Entrepreneurship

Affects The Competitive Advantage

The results of the analysis presented in table 4 shows that entrepreneurship has a significant positive effect on competitive advantage. The higher the entrepreneurial orientation the higher the competitive advantage. This result is consistent with the results of R. Duane Ireland's Justin W. Webb (2007), Sanjay Mohapatra (2012), which states that entrepreneurship is positive and significant on competitive advantage. On the other hand Deya Jared, Margaret Oloko, George Orwa, (2015), Rosa Caiazza, Aileen 


\section{Vol-2, Issue-2, 2018 (IJEBAR)}

ISSN: 2614-1280, http://www.jurnal.stie-aas/ijebar
Richardson, (2015). Roman Anton, (2016) states that the orientation of learning and entrepreneurship influences competitive advantage. Based on this description it can be said that competitive advantage is influenced by entrepreneurial orientation.

\subsection{The Influence Of Learning Orientation}

On Competitive Advantage

The results of the analysis presented in Table 4 indicate that learning orientation has significant positive effect on competitive advantage. The higher the orientation level of learning then the level of competitive advantage. Competitive advantage can be improved by improving the learning orientation. These results are in line with his research Micheels, Eric \& Gow, 2009; Wencong, et al., 2011). Which states that learning poses a significant positive effect on competing Keungglan. Meanwhile Schindehutte et al., (2008) states learning, and entrepreneurship affects Competitive Advantages. Roman Anton, (2016) also holds that the learning and entrepreneurship orientation is very keenglan keenglan compete. So based on this description can be said clearly that the orientation of learning positively significant influence on keunggulam compete.

4.5 Effect of Innovation Orientation On Organizational Performance.

The results of the analysis presented in Table 4 show that orientation orientation has significant positive effect on organizational performance. The higher the level of innovation orientation is the level of organizational performance. Organizational performance can be improved by improving the innovation orientation. These results are in accordance with the results of research from Xinming \& Yingqi, 2011 which states the orientation has positive and significant effect on the performance of the organization. These results are also not contrary to Eris \& Ozmen, 2012 which states the entrepreneurial orientation and innovation orientation affect the company's performance. Meanwhile Asdemir \& Fernando, 2013 states that innovation has an effect on organizational performance. This result is in line with the results of research from Asdemir \& Fernando, 2013 which states that price leadership and innovation orientation have an effect on performance perception. From this description it is clear that innovation orientation has a significant positive effect on organizational performance.

\subsection{Competitive Advantage Affects Performance}

The results of the analysis presented in table 4 shows that competitive advantage positively significant effect on organizational performance. The higher the level of competitive advantage will be the higher the performance of the organization. Competitive advantage will determine the performance of the organization. Meanwhile, Asdemir \& Fernando, (2013) and Ana et al., (2011) stated that the superiority in the product and in the process will have a positive and significant impact on the organization's performance. This result is logical, MSMEs that have competitive advantage its performance will be better. So to create a good performance SMEs should have competitive advantage.

\section{Closing}

\subsection{Conclusion}

Based on the results of this study can be made a conclusion: Entrepreneurship positively and significantly influence on the orientation of innovation. The higher the level of entrepreneurship orientation will be the higher level of orientation inovas. Learning orientation has significant positive effect on innovation orientation. The higher the level of implementation of the learning orientation will be the more superior an organization.

Entrepreneurship has a positive and significant effect on innovation orientation. 


\section{Vol-2, Issue-2, 2018 (IJEBAR)}

ISSN: 2614-1280, http://www.jurnal.stie-aas/ijebar

The higher the orientation of entrepreneurship the higher the orientation of innovation. Learning orientation has a positive and significant influence on competitor orientation. The higher the orientation level of learning then the level of competitor orientation is higher.

Orientation of innovation and competitive advantage positively significant effect on organizational performance. The higher the level of innovation orientation and competitive advantage, the higher the organization's performance.

This research is conducted only in

Surakarta, because the characteristics of businessmen, owners and employees of batik business have characteristics similar to those of batik business in Central Java and even Indonesia.

Future researchers can increase the number of populations and research sites more widely and more. The results can be compared with the results of this study.

\section{Reference}

Andreas, K. \& Marcus, W. (2010). The Influence of Sustainability Orientation on Entrepreneurial Intentions Investigating the Role of Business Experience, Journal of Business Venturing, Vol. 25, p. 524539.

Andrew, S. (2010). The Paradox of MarketOriented Public Policy and Poor Productivity Growth in Canada, Published in A Festschrift in Honour of David Dodge's Contributions to Canadian Public Policy, Bank of Canada.

Baker, W.E. \& Sinkula, J.M. (2009). The complementary effects of market orientation and entrepreneurial orientation on profitability in small businesses, Journal of Small
Business Management, Vol. 47. p. 443-464

Basile, A. (2012). Entrepreneurial Orientation in Smes: RiskTaking To Entering International Markets, Journal Far East Journal of Psychology and Business, Vol. 7. p. 87-103.

Chandrakumara, A., De Zoysa, A., \& Manawaduge, A. (2011). Effect of the entrepreneurial and managerial orientations of owner-managers on company performance: An empirical test In Sri Lanka. International Journal of Management, Vol.28.p.139-151

Cristina, S. (2011). The Marketing Entrepreneurship and The SMEs Competitiveness, Journal of Knowledge Management, Economics and Information Technology, Vol. 1. p. 8-25.

Deya Jared, Margaret Oloko, George Orwa, (2015),The Relationship between Dynamic Curriculum Capabilities and Competitive Advantage of Technical, Vocational and Entrepreneurship Training Institutions in Western Kenya Region, International Journal of Academic Research in Progressive Education and Development,Vol.4:3.Pp.12-23

Eris, E.D \& Ozmen, O.N.T. (2012). The Effect of Market Orientation, Learning Orientation and Innovativeness on Firm Performance: A Research From Turkish Logistics Sector Technological Educational Institute Of Kavala, International Journal of Economic Sciences and Applied Research (IJESAR), Vol. 5. p. 77108.

Fauzul, M. F., Takenouchi, H., \& Yukiko, T. 
Vol-2, Issue-2, 2018 (IJEBAR)

ISSN: 2614-1280, http://www.jurnal.stie-aas/ijebar

(2010). entrepreneurial orientation and Business performance of small and medium scale enterprises in Sri Lanka. Asian Social Science ,Vol. 6, p. 34-46.

Frishammar, J., \& Anderson, S. (2009). The overestimated role of strategic orientations for international performance of SMEs, Journal of Entrepreneurship, Vol. 7.p. 57-77.

Ghozali, I. (2008). Model Perencanaan Structural Konsep \& Aplikasi Dengan Program

Amos 16 .0,Badan Penerbit UNDIP, Semarang.

Grinstein, A. (2008). The Effect Of Market Orientation and Its Components on Innovation Consequences: A MetaAnalysis, Journal of Academy of Marketing Science, Vol. 36. p. 16673.

Hakala, H., \& Kohtamaki, M. (2010). The Interplay Between Orientations: Entrepreneurial, Thechnology And Customer Orientation In Software Companies, Journal of Entrepresing Culture, Vol. 18. p. 265-290.

Hwang, E.J. \& J. T. Norton, (2010). Market Orientation, Performance, and Perceived Environmental Uncertainty in South Korean Apparel Retail Stores, Ottawa United Learning Academy in journal Transnational Corporations Review, Vol. 2. p. 4458.

Imoleayo, F. O., (2010). The Impact of Product Price Changes on the Turnover of Small and Medium Enterprises in Nigeria, Journal brand Broad Research in Accounting, Negotiation, and Distribution, Vol. 1. p. 60-79

Ionica, D., (2010). Innovation-A Way of Increasing Small and Medium-Sized Tourism
Enterprises Competitiveness, Journal Romanian Economic and Business Review, Vol.

5. p. 156-161.

Jandaghi G. ( 2011). Market-Orientation and Its Impact on the Performance of Asia Insurance

Company in Kerman Province, Journal of Economics and Behavioral Studies, Vol.

3. p. 1-7

Jhonson, A.J. Dibrell, C.C. \& Eric, H. (2009). Market Orientation, Innovativeness, and Performance of Food Companies, Journal of Agribusiness, Vol. 27. p. 85-106

Julian, C.C. (2010). The Market OrientationMarketing Performance Relationship: The Empirical Link in International Joint Ventures Inderscience Enterprises Ltd, International Journal of Trade and Global Markets Vol. 3. p. 414-431.

Jumaev, M. Kumar, D. \& M. Hanaysha (2012) Impact Of Relationship Marketing On Customer Loyalty In The Banking Sector, Journal Far East Journal of Psychology and Business, Vol. 6. p. 36-55

Kocak, A \& Abimbola, T. (2009). The Effect of Entrepreneurial Marketing on Born Global

Performance, International Marketing Review, Vol. 26. p. 439452.

Kotler, P. (2010). Marketing Management Analysis, Planning, Implementation, and Control,

$12^{\text {th }}$ Ed. Englewood Cliff, NJ. New Jersey: Prentice-Hall, Inc.

Ledwith, A., \& Dwyer, O. (2009). Market Orientation NPD Performance, And Organizational Performance In Small Firms, Journal of Producion and 
Vol-2, Issue-2, 2018 (IJEBAR)

ISSN: 2614-1280, http://www.jurnal.stie-aas/ijebar

Innovation Management, Vol. 26.

p. 652-661.

Lewrick 1, M., M. Omar2 \& Robert L.W. Jr. (2011). Market Orientation and Innovators' Success: an Exploration of the Influence of Customer and Competitor Orientation Technol, Journal Management Innovasion, Vol. 6. p. 48-62.

Lin, C.H, Peng, C.H, \& Kao, D.T. (2008). They are Innovative Tiveness Effect of Market Orientatation and Learning Orientation is a Business Performance, Journal of Manpower, Vol. 29. p. 752-772.

Lin, C.H., C.H. Peng, \& Danny T. K. (2008). The Innovativeness Effect of Market Orientation and Learning Orientation on Business Performance, International Journal of Manpower, Vol. 29. p. 752 - 772.

Ma'atoofi, A.R. \& K.Tajeddini. (2010). The Effect of Entrepreneurship Orientation on Learning Orientation and Innovation: A Study of SmallSized Business Firms in Iran, International Journal of Trade, Economics and Finance, Vol. 1. p. 254-260.

Malcolm, S. \& Chen C. (2010). Improving customer outcomes through the implementation of customer relationship management:

Evidence from Taiwan Emerald Group Publishing in its journal Asian Review of Accounting Vol.18. p. 260-285.

Maghviroh Rovila El, (2014)Leadership Style Toward Competitive Advantage Of Business Education, Balkan Region Conference on Engineering and Business Education.Vol. 1, no.1Pp.47-50

And SME Firm Performance: Developing A Conceptual Framework, Contact:
Breen, J.Victoria University Melboune, Australiap, Vol. 8. p. 713-723.

Reijonena, H., \& komppulab, R. (2010). The Adoption of Market Orientation In Smes: Required Capabilities And Relation To Success, Journal of Strategic Marketing, Vol.

18. p. 19-37.

Rhee, J., Park, T., \& Lee, D. H. (2010). Drivers of innovativeness and performance for innovative SMEs in South Korea: Mediation of Learning Orientation Technovation, Vol. 30. p. 65-75.

Rock, A, \& Agca V. (2009). Entrepreneurial Orientation and Performance of Turkish Manufacturing FDI Firms: An Empirical Study, Journal Economics Business and Finance, Vol. 24. p. 115-133.

Rosa Caiazza, Aileen Richardson, (2015). Knowledge effects on competitiveness: from firms to regional advantage, The Journal of Technology Transfer., Vol: 40,no.6

Pp: 899-909

Roman Anton, (2016),Sustainable Intrapreneurship - The GSI Concept and Strategy - Unfolding Competitive Advantage via Fair Entrepreneurship, _ Paper provided by University Library of Munich, Germany in its series MPRA Paper with number 69713

Sanjay Mohapatra, (2012), Sustaining competitive advantage in social entrepreneurship -

a case study, Int. J. of Logistics

Economics and Globalisation, Vol.

4m no,,Pages:197-220

Sekaran, U., Roger, B. (2010). Research Methods For Business ASkill 
Vol-2, Issue-2, 2018 (IJEBAR)

ISSN: 2614-1280, http://www.jurnal.stie-aas/ijebar

Building Approarch, A John Wiley and Sons Ltd publication Fith Edition

Sergio, O. \& Roberto, F. (2008). Market orientation, knowledge related resources and firm performance, Journal of research business, Vol. 61. p. 623-630.

Shabbir, S. Ahmed, K. Kaufmann, H.R. \& Malik, E. (2010). Entrepreneur Proactiveness and Customer Value: the Moderating Role of Innovation and Market Orientation, Journal World Review of Entrepreneurship, Management and Sustainable Development, Vol.

6. p. 189-205.

Silkoset. (2009). Market Orientation Capabilities: A Study of Learning ProcessesinMarket - oriented Companies, Published at VDMVerlag, ISBN:978-3-639-04429-4.

Stare, A. (2012). The Impact of a Project Organisational Culture and Team Rewarding on Project Performance, Article Provided by Rainer Hampp Verlag in its Journal, Vol.17. p. 4067.

Tang, Z, Tang, J, Marino, L.D., Zhang, Y, \& Li, Q, (2010). An Investigation of Entrepreneurial Orientation and Organisational Strategies in Chinese
SMEs, Journal

World Review of Entrepreneurship, Management and Sustainable Development. Vol.

6. p. 206-223.

Usta, R. (2011). Strategic Orientations Enriching the Effect of Market Orientation on Company Performance: Literature-Based Holistic Model Proposal, Journal Anadolu University Journal of Social Sciences, Vol.11. p. 34-45.

Wiklund, J., Lumpkin, G.T.T. \& Frese, M. (2009). Entrepreneurial orientation and business performance: An assessment of past research and suggestions for the future, Entrepreneurship Theory and Practice, Vol. 33. p. 761-787.

Xinming, H. \& Yingqi, W. (2011). Linking Market Orientation To International Market

Selection And International Performance, Journal International Business Review Vol.

20. p. 535-546.

Zheng, Z.K, R. James, B. \& S. Chekitan, D. (2009). Market Orientation, Competitive Advantage, and Performance: A Demand-Based Perspective, Journal of Business Research, Vol. 62. p. 37-49. 